\title{
A HEXAGON RIGHT: THE SIX DIMENSIONS OF THE SOUTH AFRICAN RIGHT TO BASIC EDUCATION
}

\author{
Chiedza Simbo \\ LLB LLM LLM \\ Law Lecturer, University of Venda
}

\begin{abstract}
SUMMARY
Notwithstanding the enactment of the South African Constitution in 1996, 23 years later, the need to determine the scope and content of the right to basic education has been a battlefield for authors. Whilst authors battle, complaints are made about the South African government charging school fees for basic education, decreasing pass thresholds for matriculants, students learning in dilapidated classrooms, non-delivery of text books, unqualified teachers and many complaints reminiscent of a failing basic education system. Despite citizen attempts to take the government to court for specific violations relating to the provision of basic education, in the absence of a law of general application specifically unpacking the scope and content of the right to basic education in South Africa, an ultimate question remains, what is the scope and content of the right to basic education for the purposes of its implementation in South Africa? This paper attempts to determine the scope and content of section 29(1)(a) using an international law approach. After engaging the provisions of international law as well as writings by other authors, the conclusion is that, in relation to its scope and content, section 29(1)(a) is a hexagon right that is, a right comprising of six interrelated dimensions. The six dimensions are that, the right to basic education includes primary and secondary school attendance, the right to basic education includes compulsory and free attendance of both primary and secondary school and the right to basic education is an unqualified right. Further, the right to basic education is a minimum core content of the right to education, the right to basic education must be available, accessible, acceptable and adaptable and the quality standard of the right to basic education is explained by the World Declaration on Basic Education for All, 1990
\end{abstract}

\section{$1 \quad$ INTRODUCTION}

Conceiving education as a human right which must be provided by states has become international. A study done in 187 countries by the World Bank Research Group of Human Rights concluded that out of 165 countries which had written Constitutions, 116 had referred to the right to education, 95 of those stipulating free education for children at primary school level. ${ }^{1}$ The right to education is regarded to be so important that, to the understanding of this paper, is probably the only human right provided by international law

1 Gauri "Social Rights and Economics Claims to Health Care and Education in Developing Countries" in World Bank Policy Research Working Paper (2003) 3006. 
which is accompanied by an obligation to provide it for free at some stage of every person's life. ${ }^{2}$ With recognition of the importance and benefits of education, section $29^{3}$ of the Constitution of South Africa, 1996 (hereinafter "the Constitution") provides for the right to education. Of particular importance for this paper is that section 29(1)(a) of the South African Constitution provides that "everyone has a right to basic education". ${ }^{4}$ The constitutional provision of the right to basic education by the Constitution is commendable and in line with the international ideal to make basic education universally accessible. ${ }^{5}$

However, whilst the right to basic education is provided by international law, 23 years after the enactment of the Constitution there is no legislative document in South Africa which details the scope and content of section $29(1)(a)$ or of the right to basic education. Whilst our motivations may differ, the concern relating to the lack of a determined legally enforceable scope and content of the right to basic education is not a new conversation in South Africa. Liebenberg, ${ }^{6}$ writing on the section 29(1)(a) of the Constitution like authors such as Churr ${ }^{7}$ already recognised the absence of legal clarity relating to the scope and content of the right to basic education. Despite the lack of clarity, the importance of explaining constitutional provisions in laws of general application is noted by this paper. ${ }^{8}$ Constitutional provisions are neither exhaustive nor self-explanatory. ${ }^{9}$ Laws of general application are

2 Universal Declaration of Human Rights of 1948 Article 26(1) "1. Everyone has the right to education. Education shall be free, at least in the elementary and fundamental stages." See also Convention on the Rights of the Child of 1989 Article 28 " 1 . States Parties recognize the right of the child to education, and with a view to achieving this right progressively and on the basis of equal opportunity, they shall, in particular: (a) Make primary education compulsory and available free to all."

3 S 29 of Constitution of the Republic of South Africa 1996 "(1) Everyone has the right - (a) to a basic education, including adult basic education; and (b) to further education, which the state, through reasonable measures, must make progressively available and accessible. (2) Everyone has the right to receive education in the official language or languages of their choice in public educational institutions where that education is reasonably practicable. In order to ensure the effective access to, and implementation of, this right, the state must consider all reasonable educational alternatives, including single medium institutions, taking into account - (a) equity; (b) practicability; and (c) the need to redress the results of past racially discriminatory laws and practices. (3) Everyone has the right to establish and maintain, at their own expense, independent educational institutions that - (a) do no discriminate on the basis of race; (b) are registered with the state; and (c) maintain standards that are not inferior to standards at comparable public educational institutions. (4) Subsection (3) does not preclude state subsidies for independent educational institutions."

4 S 29(1)(a) The Constitution.

5 Mbeki The Dakar Framework for Action, Education for All: Meeting our Collective Commitments Adopted by the World Education Forum Dakar. Senegal, 26-28 April 2000 Including Six Regional Frameworks for Action Conference on Education for African Renaissance in the Twenty-first Century (6 December 1999), opening statement.

6 Liebenberg Socio-economic Rights: Adjudication under a Transformative Constitution (2010) 242.

7 Chuur "Realisation of a Child's Right to a Basic Education in the South African Constitution" 2015 PER/PELJ 72408 "It is important to note that section 29 does not specify the content and quality of the education that the state must provide nor has the South African Constitutional Court considered the scope and content of the right to basic education."

8 Du Plessis "The Status and Role of Legislation in South Africa as a Constitutional Democracy: Some Exploratory Observations" 2011 PER 149.

9 lbid. 
therefore "allies of the Constitution" and "designed to amplify and give more concrete effect to key provisions of the Constitution and the Bill of Rights". ${ }^{10}$ The need for legal documents which translate constitutional and international obligations is therefore important having been noted first by the International Covenant on Economic Social and Cultural Rights (ICESCR) which states that, citizens are not able to enjoy the human rights it provides unless state parties "take steps, including the adoption of legislative measures to fulfil the rights". ${ }^{11}$ Legislation specifying the scope and content of the right to basic education is therefore "highly desirable and in [instances such as the determination of the scope and content of the empowering right to basic education, indispensable]". ${ }^{2}$ However, the reality in South Africa is that, contrary to providing the scope and content of basic education, the Schools African Schools Act (hereinafter "the Schools Act") ${ }^{13}$ mentions the term basic education only in reference to the definition of the word minister who is referred to as the minister of basic education. ${ }^{14}$ The remaining question is what is the scope and content of the right to basic education for the purposes of its implementation in South Africa? This paper intends to answer the above question.

\section{WHY DETERMINE THE SCOPE AND CONTENT OF THE RIGHT TO BASIC EDUCATION?}

Whilst the consequences of the absent legally determinable enforceable scope and content of section 29(1)(a) maybe evident, without determining the scope and content of the right to basic education, the point at which conclusions must be drawn that the government is in violation of the right to basic education remains unclear. Whilst South Africa does not provide for a blanket free basic education, an estimated $90 \%$ of pupils in Limpopo, $72 \%$ in the Eastern Cape, 32\% in Gauteng and 28\% in the Western Cape cannot afford to pay school fees. ${ }^{15}$ It remains unclear whether or not the continued existence of fee paying schools is a violation of the right to basic education. On the delivery of the paid education, South Africa has an estimated 5139 unqualified teachers to do the job. ${ }^{16}$ There is however no clear legal basis to quickly conclude that the employment of unqualified teachers contravenes constitutional basic education obligations. After enrolling children who pay school fees, providing them with unqualified teachers and educating them for 12 years, schools have produced $0 \%$ pass rates. ${ }^{17}$ Still, without a law

\footnotetext{
Ibid.

Article 2(1) of International Covenant on Economic Social and Cultural Rights 1966. South Africa ratified the ICESCR on 12 January 2015.

2 Article 2(1) of 1966.

13 South African Schools Act No 84 of 1996.

14 Preamble of 84 of 1996.

15 "Most Pupils do not pay School Fees" http://www.news24.com/southafrica/news/mostpupils-do-not-pay-school-fees-20120503?mobile=true (accessed 2017-07-15).

16 Savides "SA Schools have 5,139 Teachers who are Unqualified or Under-qualified" http://www.heraldlive.co.za/news/2017/06/06/sa-schools-5139-teachers-unqualifiedqualified/ (accessed 2017-07-15).

17 Pieterse "0\% Pass Rate Shock" http://www.news24.com/southafrica/news/0-pass-rateschools-shock-20160111 (2017-07-15), see also Govender "Matric Results 2016: 18
} 
stipulating the foundational components of a basic education curriculum, it remains unclear whether the current curriculums whose examinations are failed by some students, aligns with the internationally recognized basic education curriculum. Schools lack learning resources such as desks, chairs, textbooks and they learn under trees or in classrooms that are dilapidated. ${ }^{18}$ It still remains unclear whether the unavailability of such education resources are a violation of the right to basic education by the governments.

Case law in South Africa has also confirmed that public schools lack teachers, textbooks, laboratories and libraries. In the case of Centre of Child Law $v$ Minister of Basic Education ${ }^{19}$ the court noted the unequal provision of teachers in public schools. ${ }^{20}$ In the case of Section $27 v$ Minister of Education the minister of basic education faced a court action for failing to provide books for learners. ${ }^{21}$ The Department of Basic Education has also confirmed that the problems with the provision of basic education resources in South Africa are "extremely serious" and "the consequences of these problems are such that many learners are already being denied their full rights to quality basic education". ${ }^{22}$ The absence of a legally clarified determined scope and content of basic education is therefore an inevitable challenge because citizens do not have a clear, undisputable and clarified legal basis to translate their complaints to legal claims. If the scope and content of basic education is ascertained, citizens can translate disgruntlements into legal entitlements and point government action or inaction as a violation of their right to basic education. Further, with a legal rubric to track compliance, governments cannot dodge accountability questions citing the absence of legal obligations on its part. The role of providing the scope and content of the right to basic education remains with the legislature and the legislature cannot delegate the duty to the judiciary which makes the determination of the scope and content of section 29(1)(a) a matter of important engagement and determination.

\section{A HEXAGON RIGHT: THE SIX DIMENSIONS OF SECTION 29(1)(A)}

In this paper, an attempt to determine the scope and content of the right to basic education takes a threefold approach. Firstly, it examines the provisions of international law relating to the scope and content of the right to basic education. Secondly, it proceeds to examine the existing research by authors in relation to the subject of basic education thereby identifying the ideas which have become agreeable among authors. Thirdly, the paper critically, where necessary, evaluates scholarly contributions against the

Schools obtain 0\% Pass Rate" Mail and Guardian https://mg.co.za/article/2017-01-05matric-results-2016-18-schools-obtain-0-pass-rate (accessed 2017-07-15).

18 Stein "Classrooms of the Future" http://www.groundup.org.za/article/classroomsfuture_2606/ (accessed 2017-07-15).

19 Centre of Child Law v Minister of Basic Education (2012) 4 All SA 35 (ECG) par 14.

20 Ibid par 17. See also Federation of Governing Bodies of South African Schools v MEC for the Department of Basic Education (unreported) 2011 Case no.60/11 par 21.

21 Section 27 v Minister of Education 2012 (3) SA 579 (GNP).

22 Centre for Child Law v Minister of Basic Education supra par 14. 
contributions made by this paper. Motivations behind standpoints taken by this paper are forwarded in order to spell out the novelty of the standpoints taken by this paper. It remains notable that, to date, no scholarly work has, to the author's knowledge, like this paper, suggested that the right to basic education in South Africa comprises of six elements. The six elements are discussed below in equal order of importance.

\section{The right to basic education is unqualified and immediately realisable}

\section{The unqualified and immediate nature of the right to basic education}

The right to basic education is an unqualified socio-economic right. ${ }^{23}$ An unqualified socio-economic right for the purposes of the Constitution is a right formulated in a manner which does not include internal qualifiers in its textual formulation. ${ }^{24}$ Internal qualifiers are words such as "access" to the right, that the right be "progressively realized" within "available resources" subject to "reasonable legislative measures" which are characteristic in the formulation of socio-economic rights. ${ }^{25}$ The point that the right to basic education is an unqualified right is not new having been accepted among many authors inclusive of Liebenberg, ${ }^{26}$ Churr, ${ }^{27}$ and Pillay ${ }^{28}$. Berger calls section 29(1) (a) a "strong positive right" due to the absence of qualifiers in its formulation. ${ }^{2}$

Interpreting the meaning of the word "access", the Grootboom case stated that "access" to housing means that the state has no entire responsibility to provide housing but it can only unlock a system which will make it possible for individuals to "access" housing. ${ }^{30}$ Eliminating the word "access" in the formulation of section 29(1) (a) should have been deliberate on the part of the constitutional drafters. ${ }^{31}$ It was meant to ensure that, the state does not only unlock a system to ensure that people have access to basic education but that the state provides basic education. ${ }^{32}$ Secondly, the provision of the right is not dependent on "reasonable legislative and other measures". Interpreting the right to housing and health, the Constitutional Court (hereinafter "court") stated that, for government programmes relating to housing, health and water to stand the test of constitutionality, the legislative

23 Woolman and Fleisch The Constitution in the Classroom: Law and Education in South Africa 1994-2008 (2009) 120.

24 Ibid.

25 Ibid.

26 Liebenberg Socio-economic Rights: Adjudication under a Transformative Constitution 242.

27 Chuur 2015 PER/PELJ 2416.

28 Liebenberg and Pillay Socio-Economic Rights in South Africa (publication Socio-economic Rights Project Community Law Centre, University of Western Cape South Africa) (2000) 351 .

29 Berger "The Right to Education under the South African Constitution" 2003103 Columbia LR 625 .

30 Government of the Republic of South Africa v Grootboom 2000 (11) BCLR 1169 par 35-37.

31 Woolman and Bishop Constitutional Law of South Africa (2008) 10.

32 lbid. 
or other measures it introduces must be reasonable. ${ }^{33}$ On the contrary, to comply with the obligations imposed by section 29(1)(a), the measures introduced by the government are not measured against reasonability. ${ }^{34}$ The government must provide basic education without fail and cannot defend its failure by professing that the measures were reasonable. ${ }^{35}$ The reasonableness approach was regarded in the Juma case as irrelevant in deciding whether or not the state had complied with its basic education obligations. ${ }^{36}$

Thirdly, section 29(1)(a) is not dependent on the availability of resources on the part of the government. ${ }^{37}$ The court has stated that obligations accruing from human rights qualified by availability of resources are only measured within the context of availability of resources on the part of the government. ${ }^{38}$ In dissimilarity section 29 (1)(a) obligations are not qualified by resource availability which means that basic education is not a right whose deprivations can be justified by resource constraints. ${ }^{39}$ Finally, the right to basic education is not qualified by "progressive realisation". The court in the Grootboom case clarified that progressive realisation is a swift, real and overtime undertaking towards the realisation of a right. ${ }^{40}$ Eliminating the progressive realisation qualifier in section 29 (1)(a) must point to the fact that, basic education is not subjected to overtime provision but rather to immediate provision. ${ }^{41}$ The contrast between the textual formulation of section 29(1)(a) and section (29) (1) (b) which provides for progressive further education became a point of emphasis in the Governing Body of the Juma Musjid Primary School v Essay N.O. (hereinafter "the Juma case") when the court reasoned that basic education was intended as an unqualified immediately claimable right. ${ }^{42}$

Taking into account the textual formulation of the right to education and the absence of internal qualifiers in its formulation, in the Juma case ${ }^{43}$ the

33 Lindiwe Mazibuko $v$ City of Johannesburg Case 2010 (4) SA 1 (CC) par 49-50. In the Mazibuko case, the court stated that s 27 (1) does not entitle anyone a claim of water but the government must ensure that it puts in place reasonable measures to ensure that water is accessible. See also Government of the Republic of South Africa v Grootboom supra par 39-44. Further, in the Grootboom case, the Constitutional Court noted that reasonable measures did not constitute the provision of a house but included the provision of temporary accommodation and constructive engagement, which would ensure humane evictions.

34 Woolman and Fleisch The Constitution in the Classroom: Law and Education in South Africa 1994-2008 121.

35 Ibid.

36 Governing Body of the Juma Musjid Primary School v Essay N.O. 2011 (8) BCLR 761 par 36-38.

37 Woolman and Fleisch The Constitution in the Classroom: Law and Education in South Africa 1994-2008 121.

38 Government of the Republic of South Africa $v$ Grootboom supra par 46. See also Soobramoney $v$ Minister of Health 1998 (1) SA 765 (CC) par 11.

39 Berger 2003103 Columbia LR 625.

40 Government of the Republic of South Africa $v$ Grootboom supra par 45 . See also Lindiwe Mazibuko v City of Johannesburg supra par 49-50. The court stated that it is insufficient for the government to show that the policy it has selected is reasonable, it must also show that the policy is consistent with the obligation to "progressively realise" socio-economic rights.

41 Berger 2003103 Columbia LR 625.

42 Governing Body of the Juma Musjid Primary School v Essay N.O. supra par 36-38.

43 Ibid. 
court stated that, dissimilar to some of the other socio-economic rights, section 29(1)(a) is unqualified and also immediately realisable. ${ }^{44}$ Quoting the case of Juma the court stated that:

"It is important for the purposes of the judgment, to understand the nature of the 'right to basic education' under section 29(1)(a). Unlike some of the other socio-economic rights, this right is immediately realisable. There is no internal limitation [in the text] requiring the right to be 'progressively realized' within 'available resources' subject to 'reasonable legislative measures'. The right to basic education in section 29(1)(a) maybe limited only in terms of the law of general application, which is 'reasonable and justifiable in an open and democratic society based on human dignity, equality and freedom'. This right is therefore distinct from the right to 'further education' provided in section 29

(1) (b). The state is in terms of that right, obliged to take reasonable measures

to make further education 'progressively available and accessible'."

To reinforce the position of the Juma case, the court in the case of $M$ Madzodzo obo Parents of Learners and the Minister of Basic Education also stated that the right to basic education is an unqualified right which is not subject to any limitations other than by law of general application. ${ }^{46}$

\section{Immediate realisability of section 29(1)(a) and section 36 of the Constitution}

Whilst the authors already agree that the right to basic education is unqualified and immediately realisable, McConnache and MacConnache agree with the unqualified nature but dispute its immediate realisability. ${ }^{47}$ They accept that the right to basic education is an unqualified right but argue that although it is unqualified, the right to basic education "does not mean that the state will be required to provide adequate facilities immediately, irrespective of budgetary and capacity constraints or other urgent demands on its resources". ${ }^{48}$ They defend their analysis by stating that, the state can justify its failure to deliver the right to basic education using the limitation clause of the Constitution (s 36). ${ }^{49}$ Section 36 states that, human rights in the bill of rights can be limited in terms of the law of general application in consideration of the nature of the right and to the extent that the limitation is justifiable in a value based society. The limitation will therefore always take into account the nature of the right. ${ }^{50}$ The argument by McConnache and MacConnache that the right to basic education cannot be immediate because of the provisions of section 36 is regarded incorrect by this paper. To begin with, section 36 of the Constitution states that all human rights qualified or unqualified may be limited by the law of general application as long as the limitation takes into account the nature of the right. ${ }^{51}$ Whilst

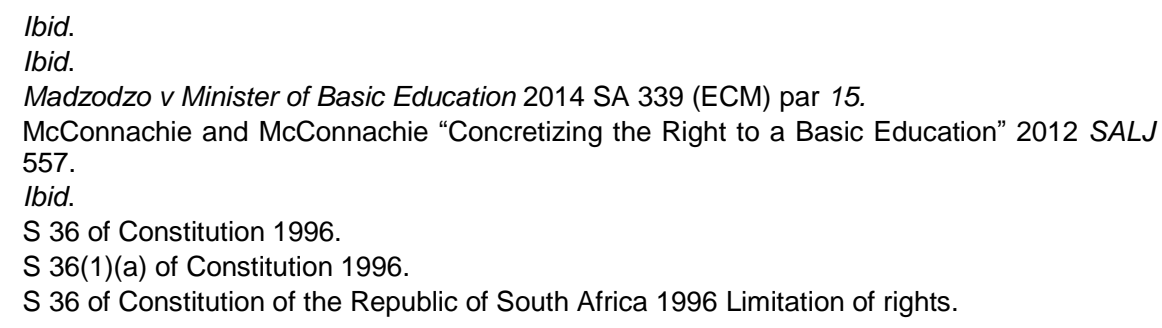


section 36 limits the enjoyment of rights based on reasonableness and justifiability, it is the proposition of this paper that it cannot alter the internally qualified and unqualified nature of a right. Indeed, despite the provisions of section 36, the Juma case stated unequivocally that, by virtue of its formulation which does not include qualifiers, basic education is an immediately realizable right. ${ }^{52}$ Any provision of a right to basic education qualifying it on the basis of resource, reasonable or other constraints cannot be a section 36 limitation and is therefore unconstitutional. In the view of this paper, an example of a limitation of basic education envisaged by section 36 is a declaration by the government that the national examination paper has leaked and scheduled examinations need to stop until a specific time. Such a declaration can be challenged but as required by section 26 , the state will have the obligation to prove that the limitation fits the section 36 criterion.

Whilst the reasoning of this paper is that section 36 cannot qualify the unqualified nature of the right to basic education but can only limit its enjoyment in justifiable circumstances, practical concerns remain. Even if we agree that basic education is an immediate obligation, realistically, when demands are made, the question of availability of resources will arise either within the ministry of basic education, in parliament or in court. The state will likely argue that amid competing claims to provide other socio-economic rights, it is impossible for it to provide the free right to basic education immediately for every child due to resource constrains. Like it has done in the past, in cases such as that of Centre of Child Law $v$ Government of the Eastern Cape Province ${ }^{53}$ and the School Governing Body of Amasango Career School v MEC for Education Eastern Cape ${ }^{54}$ the state will likely lean towards settlements and five year plans. Such an approach is viewed by this paper as unconstitutional as it makes the right to basic education progressive thereby qualifying it on the basis of resources. Constitutionally, the state has no other constitutional immediate legal constitutional socioeconomic obligation which competes with basic education. The state has no duty to deliver the further education, housing, water or food immediately but rather to only provide access to plans or programmes within its available resources in line with the reasoning of the Grootboom and Treatment Action

"36(1) The rights in the Bill of Rights may be limited only in terms of law of general application to the extent that the limitation is reasonable and justifiable in an open and democratic society based on human dignity, equality and freedom, taking into account all relevant factors, including -

(a) the nature of the right;

(b) the importance of the purpose of the limitation;

(c) the nature and extent of the limitation;

(d) the relation between the limitation and its purpose; and

(e) less restrictive means to achieve the purpose.

(2) Except as provided in subsection (1) or in any other provision of the Constitution, no law may limit any right entrenched in the Bill of Rights."

52 Governing Body of the Juma Musjid Primary School v Essay N.O. supra par 26-38.

53 Centre of Child Law v Government of the Eastern Cape Province ECB (unreported) case number 504/10.

54 School Governing Body of Amasango Career School v MEC for Education Eastern Cape ECG (unreported) case number 3838/2009. 
Campaign. ${ }^{55}$ If the state chooses to spend money delivering further education, housing, water or food immediately and for free then such selfimposed obligations cannot be viewed as obligations which compete with the right to basic education. What is needed is for the state to understand its immediate constitutional obligations and divert energy and resources towards financing and providing basic education. This would mean that the provision of further education, housing, water or food will have to be limited to the provision of access to measures required by the Constitution.

\section{The right to basic education is the minimum core content of the right to education}

\section{The minimum core concept}

Following the above argument that basic education is an unqualified right, is the reasoning that it is also the minimum core obligation of the right to education. ${ }^{56}$ The minimum core concept was first described by General Comment 3 to the ICESCR and it points to the fact that each right has an extent of its provision which satisfies its minimum fulfillment. ${ }^{57}$ General Comment 3 states that:

"The Committee is of the view that a minimum core obligation to ensure the satisfaction of, at the very least, minimum essential levels of each of the rights is incumbent upon every state party. Thus, for example, a state party in which any significant number of individuals is deprived of essential foodstuffs, of essential primary health care, of basic shelter and housing, or of the most basic forms of education is, prima facie, failing to discharge its obligations under the Covenant. If the Covenant were to be read in such a way as not to establish such a minimum core obligation, it would be largely deprived of its raison d'être."

The minimum core approach envisages that there is a compulsory minimum fulfilment of a right incumbent upon a state. ${ }^{59}$ The minimum core approach proposes an unqualified immediate priority of a right which a state must provide. ${ }^{60}$ The provision of a minimum core is aimed at being universal although its elaborate details may vary from context to context. ${ }^{6 \mathrm{~T}}$ The state whose people are deprived of the minimum level of provision of a right is considered to be in breach of its ICESCR obligations. ${ }^{62}$ The minimum core is

55 Government of the Republic of South Africa $v$ Grootboom supra and Minister of Health $v$ Treatment Action Campaign 2002 (10) BCLR 1075.

56 Simbo "The Right to Basic Education, The South African Constitution and The Juma Musjid Case: An Unqualified Human Right and A Minimum Core Standard" 201317 Law Democracy and Development 491.

57 Chowdhury "Judicial Adherence to a Minimum Core Approach to Socio-Economic Rights. A Comparative Perspective" 2009 Cornell Law Library 3.

58 Par 10, General Comment No. 3: The Nature of States Parties' Obligations, 1990.

59 Chowdhury 2009 Cornell Law Library 3.

60 Wesson "Grootboom and Beyond; Reassessing the Socio-economic Jurisprudence of the South African Constitutional Court" 200420 SJHR 298.

61 Coomans "Identifying the Key Elements of the Right to Education: A Focus on its Core Content" https://www.crin.org/en/docs/Coomans-CoreContent-Right\%20to\%20Education CRC.pdf (accessed 2017-07-15).

62 Par 30 of General Comment No. 31990. 
therefore a "floor beneath which the conduct of the state must not drop if there is to be compliance with the obligation". ${ }^{63}$

Deliberating on the applicability of the minimum core when interpreting socio-economic rights, the Court in the Grootboom case, expressed concern stating that, it would be difficult to determine the minimum core of the right to housing, "without having the requisite information on the needs and the opportunities for the enjoyment of this right. This court [did] not have comparable information". ${ }^{64}$ The court expressed that determining the minimum core content of housing is difficult because the housing needs of people are different. ${ }^{65}$ The court then stated that in light of the progressive obligations on the state, "the real question in terms of our Constitution is whether the measures taken by the state to realise the right afforded by section 26 are reasonable". ${ }^{66}$ In like manner, in the Treatment Action Campaign case the court stated that it would be impossible for it to determine what a minimum core right to health would be. ${ }^{67}$ Based on its inability to determine the minimum health needs for different individuals, the court denied that the minimum core applies to the interpretation of socioeconomic rights in South Africa. ${ }^{68}$

\section{The denial of the applicability of the minimum core in South Africa and the right to basic education}

It is notable that the denial of the applicability of the minimum core concept was done when the court deliberated on wholly qualified socio-economic rights which by their formulation neither attract immediate obligations nor comprise of unqualified obligations. ${ }^{69}$ As the court stated in the Grootboom case, it would be difficult to determine a minimum core obligation of a right which must be progressively realised and whose compliance is measured by reasonable measures. ${ }^{70}$ Whilst the court's reasoning may be debatable, it is notable that, the provision of progressively realisable rights by the Constitution may point to the intention by the legislature to have no part of them as immediate. ${ }^{71}$ On the other hand, the provision of the right to basic education as a qualified right points to the unique and immediate obligations the constitutional drafters intended to impose upon the state. ${ }^{72}$ Also, unlike health and shelter which presents diverse needs for individuals, education is a uniform need for everyone and the world has already agreed through the

\footnotetext{
Par 31 of General Comment No. 31990

Government of the Republic of South Africa v Grootboom supra par 32.

Ibid.

Ibid.

Minister of Health $v$ Treatment Action Campaign supra par 26-39.

Ibid.

Simbo 201317 Law Democracy and Development 491.

Government of the Republic of South Africa v Grootboom supra par 32

Mbazira Litigating Socio-economic Rights in South Africa: A choice between Corrective and Distributive Justice (2009) 58.

72 Simbo 201317 Law Democracy and Development 491.
} 
World Declaration that basic education is the type of education which must be acquired by every human being. ${ }^{73}$

Further, in relation to the right to education, the court will not be burdened with the obligation to determine the minimum core of the right in section 29. Section 29(1)(a) already provides a right which in its formulation provides for immediate unqualified obligations similar to a minimum core obligation. ${ }^{74}$ The court will simply take note of the similarity and treat the right to basic education as the minimum fulfilment of the right to education. ${ }^{75}$ Also, it is also notable that South Africa recently ratified the ICESCR and incompliance with its obligations, the legislature should clarify the minimum core content of the right to basic education. ${ }^{76}$ The choice of basic education as the minimum core compliance with the right to education should be motivated by the fact that, the unqualified nature of the obligations imposed by section 29(1)(a) are similar to the unqualified obligations imposed on every state by the ICESCR.

\section{The right to basic education is provided at primary and secondary school levels}

The other component of the right to basic education is that it encompasses primary and secondary school attendance. The South African case of Madzodzo v Minister of Basic Education already confirmed the importance of school attendance stating that, "access to schools is a necessary condition for the achievement of the right to education" ${ }^{78}$ School attendance is not the basic education but is it an input which enables the channeling of the basic education. ${ }^{79}$ General Comment 13 to the ICESCR states that the close relationship between primary education and basic education is that, outside the family, the primary school is the central conveyancing system for basic education. ${ }^{80}$ In accordance with General Comment 13, primary education is the stage where basic education is first introduced. ${ }^{81}$ Whilst General Comment 13 states that primary education is the main delivery of basic

\footnotetext{
Simbo 201317 Law Democracy and Development 493.

Ibid.

Ibid.

76 Par 10 of General Comment No. 3: The Nature of States Parties Obligations 1990 "On the basis of the extensive experience gained by the Committee, as well as by the body that preceded it, over a period of more than a decade of examining States parties' reports the Committee is of the view that a minimum core obligation to ensure the satisfaction of, at the very least, minimum essential levels of each of the rights is incumbent upon every State party. Thus, for example, a State party in which any significant number of individuals is deprived of essential foodstuffs, of essential primary health care, of basic shelter and housing, or of the most basic forms of education is, prima facie, failing to discharge its obligations under the Covenant. If the Covenant were to be read in such a way as not to establish such a minimum core obligation, it would be largely deprived of its raison d'être."

78 Madzodzo v Minister of Basic Education supra par 1. "This matter concerns the impact of an alleged failure to provide essential school furniture, in the form of desks and chairs, to public schools throughout the Province and in particular in impoverished rural areas." Par 13(9) of General Comment 13: The Right to Education.
}

77 Ibid.

80 Ibid.

81 Ibid. 
education it further states that secondary education "includes the completion of basic education". ${ }^{82}$ The provisions of the General Comment 13 mean that, basic education is first provided at primary school levels and completed at secondary school levels.

In addition to General Comment 13 provisions, in the context of South Africa which is party to the ICESCR, the provisions of General Comment 13 are read together with the provisions of the African Charter on the Rights and Welfare of the Child (hereinafter "the African Charter") ${ }^{83}$ which is also binding on South Africa. The African Charter does not provide for provisions relating to primary and secondary school attendance but it places an obligation on member states to make the acquisition of basic education mandatory ${ }^{84}$ The additional non-derogatory obligation imposed on South Africa by the African Charter of requiring states to make the acquisition of basic education mandatory are interpreted by this paper to mean that, as long as there is an international acceptance that basic education is offered at both primary and secondary levels as stated by General Comment 13, both primary and secondary school attendance is also compulsory.

Although the Schools Act does not provide clarity relating to the school levels for which basic education is offered, it is understood that, since the ministry of basic education in South Africa regulates the provision of education from grade 1 to grade 12 including adult literacy programmes, basic education is provided at primary and secondary school levels. ${ }^{85}$ Arendse following the argument by Coomans however notes that primary education is the most important level of education which can even translate to being the minimum claim that should be demanded by citizens. ${ }^{86}$ The regard of primary education as the minimum claim minimizes the importance of secondary education. As stated above, basic education is the minimum core content of the right to basic education. For children to acquire full basic education needs, they must attend both primary and secondary school levels in compliance with both the African Charter and General Comment 13

82 General Comment 13, 1990 par 12, "While the content of secondary education will vary among States parties and over time, it includes completion of basic education and consolidation of the foundations for life-long learning and human development. It prepares students for vocational and higher educational opportunities.7 Article 13(2)(b) applies to secondary education 'in its different forms', thereby recognizing that secondary education demands flexible curricula and varied delivery systems to respond to the needs of students in different social and cultural settings. The Committee encourages alternative educational programmes which parallel regular secondary school systems."

83 Article 11(3)(a) of African Charter on the Rights and Welfare of the Child 1990 "State Parties to the present Charter shall take all appropriate measures with a view to achieving the full realization of this right and (a) shall in particular provide free and compulsory basic education."

84 Ibid.

85 Department of Basic Education "About Basic Education" http://www.education.gov.za/ AboutUs/AboutDBE.aspx (accessed 2017-07-15), "The Department of Basic Education was formed when the former National Department of Education was split into two: Department of Basic Education and the Department of Higher Education and Training. The DBE deals with all schools from Grade R to Grade 12 including adult literacy programmes. The aim of the DBE is to develop, maintain and support a South African school education system for the 21st century."

86 Arendse "The Obligation to Provide Free Basic Education in South Africa: An International Law Approach" 201114 PER/PELJ 217. 
provisions discussed above. Both primary and secondary school attendance are therefore a component of the right to basic education.

\section{Free and compulsory education as an important component of basic education}

\section{Compulsory basic education}

Indeed, in addition to its provision at primary and secondary school levels as discussed above, basic education must be provided freely and compulsorily. On the aspect of compulsory basic education, the Schools Act in partial compliance with international law provides for compulsory primary education. ${ }^{87}$ Article 26(1)(a) of the Universal Declaration states that, "everyone has the right to education. Elementary education shall be compulsory". ${ }^{88}$ The ICESCR provides that, "primary education shall be compulsory" whilst secondary education must be accessible. ${ }^{89}$ State parties to the Convention of the Rights of the Child (CRC) also agreed that, primary education must be compulsory whilst secondary education is accessible. ${ }^{90}$ The Schools Act by making primary education compulsory, mirrors the objectives of international law which intends to ensure that children are able to attend school without interference from anyone including their parents. It is notable that, as discussed above, the African Charter provides that, basic education, not only primary education, must be compulsory. ${ }^{91}$ If South Africa provides clarity in the future that, in line with international law, basic education is offered at both primary and secondary school levels in South Africa, the Schools Act must also provide for both compulsory primary and secondary education.

\section{Free basic education and the critique of the South African fee system for children}

In terms of the provision of free basic education, the obligation to provide free education at primary school is viewed as unequivocal at international law. The Universal Declaration states that, education "shall be free at

\section{S 3(1) of 84 of 1996.}

8 Article 26(1) of Universal Declaration of Human Rights 1948. "Everyone has the right to education. Education shall be free, at least in the elementary and fundamental stages. Elementary education shall be compulsory. Technical and professional education shall be made generally available and higher education shall be equally accessible to all on the basis of merit. (2) Education shall be directed to the full development of the human personality and to the strengthening of respect for human rights and fundamental freedoms. It shall promote understanding, tolerance and friendship among all nations, racial or religious groups, and shall further the activities of the United Nations for the maintenance of peace."

89 Article $131(\mathrm{a})$ and (b) of International Covenant on Economic, Social and Cultural Rights1966.

90 Article 28(1)(a) of Convention on the Rights of the Child 1989.

91 Ibid. Article 11(3)(a) State Parties to the present Charter shall take all appropriate measures with a view to achieving the full realization of this right and (a) shall in particular provide free and compulsory basic education. 
elementary [primary] levels". ${ }^{92}$ The ICESCR states that primary education must be compulsory and free whilst secondary education must be accessible, available and progressively free. ${ }^{93}$ The CRC states that primary education must be both compulsory and free whilst secondary education must be accessible, available and gradually free. ${ }^{94}$ The African Charter, to which South Africa is party, extends the obligation to provide free basic education throughout the basic education years.

The Schools Act does not provide for free education at any level including the primary school but provides for a no fee and fee exemptions. By a majority vote, parents may adopt a resolution to charge school fees at a public school. ${ }^{96}$ The resolution must state the amount of school fees to be charged. ${ }^{97}$ A parent can be partially or totally exempted from paying school fees and the school governing body has the responsibility to implement such a resolution. ${ }^{98}$ Unless exempted, every parent has the obligation to pay school fees and is legally liable for failure to do so ${ }^{99}$ A parent has the right to lodge an appeal with the head of department against the decision of the governing body concerning exemption from paying school fees and the head of department must make a decision after considering the interest of the parent as well as those of the governing body. ${ }^{100} \mathrm{~A}$ parent who fails to apply for exemption to pay school fees after being notified of such failure by the school and fails to pay school fees after three months from such notification may have legal proceedings commenced against them for such liability. ${ }^{101}$

The means test which compares the income of the parent(s) of the child relative to the fees that the child has to pay is the basis to exempt a learner from paying school fees. ${ }^{102}$ The Regulations Relating to the Exemption of Parents from the Payment of schools fees 2006 provide an application form that parents must fill and apply to the Chairperson of the School Governing Body (SGB). ${ }^{103}$ Children who are automatically exempted from paying school fees include children in foster care, in a youth centre, in a place of safety, in an orphanage, abandoned children, a child who heads a family, a child

\footnotetext{
Universal Declaration of Human Rights 1948 S 26(1).

Article 13(a) and (b) International Covenant on Economic, Social and Cultural Rights 1966.

S 28(1)(a)(b) of Convention on the Rights of the Child 1989.

Article 11(3) of African Charter on the Rights and Welfare of the Child 1990

S 39(1) of 84 of 1996.

S 39(2)(a) of 84 of 1996.

$\mathrm{Sec} 39(2)(\mathrm{b})$ and (3) of 84 of 1996.

99 Sec 40(1) of 84 of 1996.

$100 \mathrm{Sec} 40(2)$ and (3) of 84 of 1996.

$101 \mathrm{~S} 40(1)$ to (6) of 84 of 1996.

102 Hall and Monson "Free to Learn: The School Fee Exemption Policy and the National School Nutrition Programme" http://docplayer.net/12058666-Education-is-a-basic-right-section-291-a-of-the.html (accessed 2017-07-15). "The Exemption of Parents from the Payment of School Fees Regulations of 1998 set out a mandatory minimum means test for the granting of exemptions. During the Means to Live research period, the means test read as follows: If the combined annual gross income of the parents is less than ten times the annual school fees per leaner, the parent qualifies for full exemption. Partial exemptions were available for those whose income was more than ten times but less than thirty times the annual fees."

103 Department of Basic Education "Guide for Parents: School Fees in Public School" http://www.ecdoe.gov.za/documents/parents/tips/tips-for-parents.pdf (accessed 2017-0717).
} 
without support or a child on a child's grant. ${ }^{104}$ To get an automatic exemption a parent or guardian must have a sworn statement or affidavit that is confirmed by the South African Police Service, any social worker or competent authority stating that the child is eligible for exemption or must have a court order confirming the exemption. ${ }^{105}$ The documents must be handed to the principal of the school or a member of the SGB. ${ }^{106}$

By way of a government notice the Minister may gazette the "national quintiles for public schools or part of such quintiles which must be used by the Member of the Executive Council ${ }^{107}$ to identify schools that may not charge school fees". ${ }^{108}$ The implication of the above is that whilst other public schools may charge school fees there are others which may be identified and determined as no-fee schools. ${ }^{109}$ The no-fee policy states that the poorest $40 \%$ of schools should not charge school fees only from grade $R$ to grade 9 and its first implementation was in $2007 .{ }^{110}$ To help in informing its judgment on the names of the $40 \%$ that should not charge school fees, the Department of Basic Education "allocates each school a poverty ranking derived from national data on income levels, dependency ratios and literacy rates in the surrounding community". ${ }^{111}$ The Minister then states that a school is a no-fee school by publishing it in the Government Gazette currently all schools ranked in quintiles 1,2 and 3 should be no-fee schools. ${ }^{112}$ The government then pays to cover the costs of non-fee paying learners from its national budget. ${ }^{13}$ The ranking of no-fee schools is according to the area in which the schools are situated, meaning that children who go to school in areas not depicted as poor have to pay schoolfees. ${ }^{114}$

Whilst the South African system seems to be noble in its provision of nofee schools and fee exemptions, it is not in compliance with the international law obligations to provide free primary education, progressively free secondary education and free basic education. In fee paying public schools, the Schools Act gives parents the power to determine the amount of school fees to charge. ${ }^{115}$ Such an approach means that the level of income of parents at each public fee paying school has the potential to indirectly determine the social class of children who will attend that school. It goes without saying that a school whose learners' parents are wealthy can afford

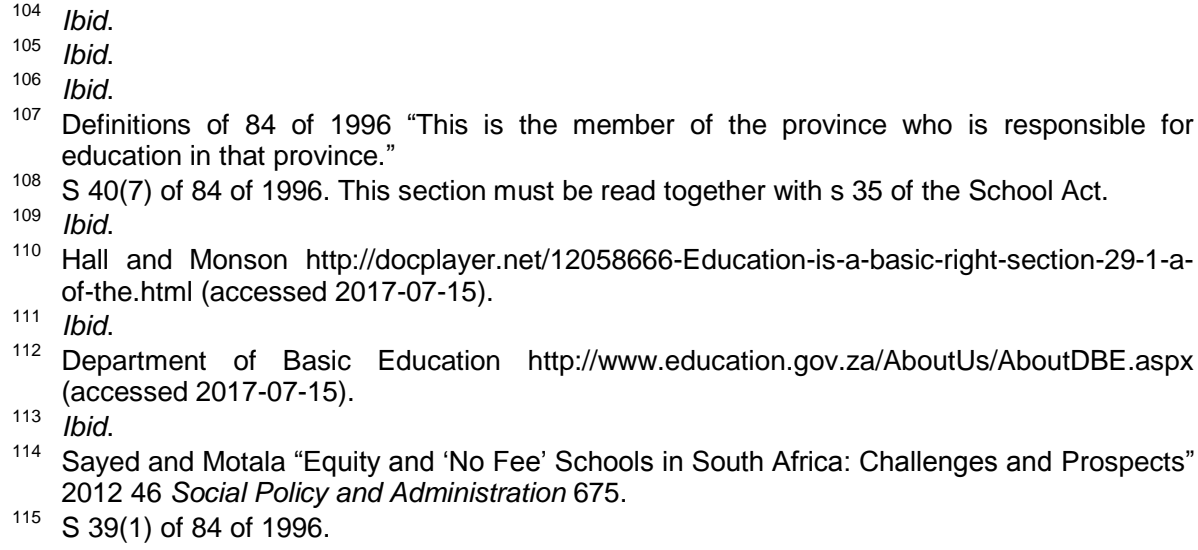

114 Sayed and Motala "Equity and 'No Fee' Schools in South Africa: Challenges and Prospects" 201246 Social Policy and Administration 675.

115 S 39(1) of 84 of 1996. 
to attract better teachers, to hire the teachers they want, to buy books for children and to provide the best learning facilities. Such potential disparities in the funding of education especially at public schools is against discrimination in education as it is defined by the Convention Against Discrimination in Education (CADE) which shuns the provision of education of an inferior standard for anyone. ${ }^{116}$ It perpetuates the unequal distribution of educational opportunities for children thereby discriminating other children based on the financial status of their parents. Also, consequent to poor education which is almost a direct consequent of the poverty of their parents, children of poor parents may end up poorly educated and remain marginalized in their adulthood.

In the view of this paper, the fee exemption policy is also discriminatory in that it directly places the fate of children from poor backgrounds in the hands of more affluent parents who vote to determine whether or not they can be exempted from paying school fees. Such a situation can potentially expose the children and their poor parents and make them vulnerable to discrimination by other parents, teachers or even students. The fee exemption policy is therefore blind to the exceptionally difficult situation of lack and want that children with poor parents may have grown up in and their need for special attention that does not expose them to further alienation and discrimination. No child deserves to feel that they are getting basic education because other parents, teachers and learners have felt pity for them and condoned their parents for being poor. Further to the above, the fee exemption policy only applies to public schools and leaves no room for a private school to be compelled to exempt a child from paying school fees. By not extending the fee exemptions to private schools there is a chance that children of domestic workers living with their mothers in wealthy suburbs might not find a no-fee paying public school nearby for their children and yet they still do not afford to take their child to a private school. The end result might be that the school children will either be separated from their working parent/parents to ensure that they get educated in a no-fee paying public school elsewhere or the child might be forced to walk long distances to a no-fee paying school.

In addition to the discrimination perpetrated by the fee exemption policy, the no fee system as well as fee exemptions both disadvantage children of well-resourced parents by assuming that because their parents are well resourced, they will consequently provide school fees for them. That assumption is discriminatory by its ability to place the purported rich children at the mercy of irresponsible parents. A child is entitled to free primary education and must never beg a parent to pay their fees. Also, children from the deemed rich backgrounds are also at risk of dropping out of school as soon as their parents become poor, die or simply refuse to pay school fees.

116 Article (1)(a)(b) Convention Against Discrimination in Education (CADE). To define discrimination in education, the Convention states that it "includes any distinction, preference, limitation or exclusion based on factors including economic status, race, color and sex. In particular the Convention mentions that discrimination includes the deprivation of access to any type of education for a specific group of persons, the provision of education of an inferior standard to certain persons, the establishment of separate education systems for specific persons and groups or the imposition of undignifying education conditions on one specific group of persons". 
The Committee on Economic Social and Cultural Rights (CESCR) elaborated that the right to free primary education is a right for every child regardless of his/her background. The CESCR reinforce states that:

"Free of charge: The nature of this requirement is unequivocal. The right is expressly formulated so as to ensure that availability of primary education without charge to the child, parents or guardians. Fees imposed by the government, the local authorities or the school, and other direct costs, constitute disincentives to the enjoyment of the right and may jeopardize its realization. They are also often highly regressive in effect. Their elimination is a matter which must be addressed by the required plan of action. Indirect costs, such as compulsory levies on parents (sometimes portrayed as being voluntary, when in fact they are not), or the obligation to wear a relatively expensive school uniform, can also fall into the same category."

The fee exemption policy is also discriminatory by being based on a rational of cross-subsidization where higher school fees might have to be paid by the more affluent parents to cater for the needs of the less affluent. ${ }^{118}$ This means that in fee paying public schools as school fees are increased to cater for the underprivileged children partially/fully exempted from paying school fees, the number of children who fall into the exempted category might increase as salaries of parents might not go up. The situation above leads to a vicious cycle that might see the affluent parents shouldering the burden of paying school fees for indigent students and consequently opting to take their children to private schools where there are no-fee exemptions. ${ }^{119}$ Further, the use of income to determine poverty of parents to determine exemptions often prejudices those who are slightly above or below the poverty line. ${ }^{120}$ The no fee system like fee exemptions is also discriminatory in that it is based on the assumption that learners in schools come from the communities in which the school is situated which is not necessarily the case in all circumstances and can lead to wrong assumptions on reaching decisions about the list of schools that qualify for the no-fee policy. ${ }^{121}$ Moreover, using the school and not the child as the unit of analysis to conclude whether the child should pay school fees hides the problems of the individual learner which are supposed to be of paramount importance under the principle of the best interest of the child. ${ }^{122}$

The importance of education calls for a more serious commitment on the part of South Africa. Given the proven benefits of education in alleviating poverty and promoting human development and the development of nations, an argument that the immediate free and compulsory provision of basic education is not possible due to resource constraints is neither constitutional nor sustainable. It must be noted that "energy and funding directed to basic education [is] perhaps the most profound investment in people and in the future of a country". ${ }^{13}$ The South African Constitution provides for an

117 Committee on Economic, Social and Cultural Rights, General Comment No. 111999 par 7.

118 Libisi The Quest for Free Education in South Africa: How close is the Dream to Reality (2008) 5 .

119 Libisi The Quest for Free Education in South Africa: How close is the Dream to Reality 10.

120 Libisi The Quest for Free Education in South Africa: How close is the Dream to Reality 11.

121 Ibid.

122 Libisi The Quest for Free Education in South Africa: How close is the Dream to Reality 5.

123 Article IX(1) of World Declaration Article 1990. 
unqualified right to basic education, it gives paramount importance to the provisions of international law and it is bound by its ICESCR and African Charter obligations which all demand that South Africa provides for free basic education. As long as parents are guilty of failure to send children to school, basic education must be provided for free. Parents cannot be expected to pay the money they do not have and be punished for not paying what they do not have.

\section{Basic education points to the quality of education}

\section{The difference between the term basic education and the right to basic education}

Firstly, it is already accepted reasoning among authors such as McConnachie, McConnachie ${ }^{124}$ and Murungi ${ }^{125}$ that in relation to its definition, the term basic education is quality oriented and defined by the World Declaration. ${ }^{126}$ In the understanding of this paper, there is a need to note from the onset the difference between the right to basic education and the term basic education. The right to basic education is the one whose scope and content this paper intends to determine whilst the term basic education is a quality oriented term which points to the quality of education which children must acquire. ${ }^{127}$ The quality component of education called basic education is in the view of this paper, another component of the right to basic education. The term basic education is viewed to have originated from, is defined and unpacked by the World Declaration on Education for All, 1990 (hereinafter "the World Declaration") points to the quality of education that learners must receive. ${ }^{128}$

\section{Quality: The heart of the education goal}

From the time of the Universal Declaration, quality was at the heart of the Education for All goals. Education was always supposed to have a certain standard that enables human beings to develop as individuals and members of the society. In relation to the quality of education, the Universal Declaration states that the aim of education must be the full development of the personality of the human being and the strengthening of their respect of human rights and freedoms. ${ }^{129}$ Further, education must promote the friendship of nations, tolerance, understanding and the maintenance of peace. ${ }^{130}$ The ICESCR echoing the provisions of the Universal Declaration

124 McConnachie and McConnachie 2012 SALJ 565-568.

125 Murungi "Inclusive Basic Education in South Africa: Issues in its Conceptualisation and Implementation" 201518 PER 1.

126 Berger 2003103 Columbia LR 625. See also McConnachie and McConnachie 2012 SALJ 127.

127 lbid.

128 World Declaration 1990.

129 Article 26(2) of Universal Declaration of Human Rights 1948.

130 lbid. 
states that education must be aimed at the full development of the individual, which shall promote human dignity and strengthen the enjoyment of other human rights. ${ }^{131}$ An education provided by the state must aim at enabling people to participate fully in society, promote friendship, understanding and tolerance amongst nations as enunciated by the Universal Declaration. ${ }^{132}$ The CADE also echoes the provisions of the Universal Declaration stating that education must aim at developing the human personality and strengthening their respect of human rights and fundamental freedoms and that it must promote "understanding, tolerance and friendship among all nations and the maintenance of peace".

The African Charter on the Rights echoing the provisions of the Universal Declaration of Human Rights states that education must aim at fostering the respect of human rights and freedoms. ${ }^{134}$ It further states that an education must aim at preserving African moral virtues, cultures and traditional values which are progressive. ${ }^{135}$ It must prepare the child to live freely and responsibly in the spirit of "tolerance, dialogue, mutual respect and friendship around all people ethnic, tribal and religious groups". ${ }^{136}$ Education must particularly aim at directing the African child towards the preservation of their national independence and the integrity of their territory. ${ }^{137}$ It must aim to promote unity among Africans and foster their solidarity, the respect of their environment as well as natural resources. ${ }^{138}$

\section{The quality-oriented term basic education}

In relation to the term basic education, Liebenberg and Pillay conclude that basic education is a term which alludes to compulsory school attendance up to age 15 or grade $9 .^{139}$ This approach is regarded as incorrect because as clarified earlier school attendance is only a means for children to acquire basic education. The correct position as stated by Woolman and Fleisch is that the term basic education is quality oriented. ${ }^{140}$ Woolman and Fleisch elaborated their position quoting two American cases Campaign for Fiscal Equity v The State of New York 100 NY 2d 893 and Campaign for Fiscal Equity ${ }^{141}$ which illustrated the term basic education as quality oriented and spoke to some quality aspects such as literacy and skills. ${ }^{142}$ Indeed, clarifications relating to the type of education which must be provided for

\footnotetext{
Article 13(1) of International Covenant on Economic, Social and Cultural Rights1966.

lbid.

Article 1(5)(a) of Convention Against Discrimination in Education 1960.

Article 11(1-7) of African Charter on the Rights and Welfare of the Child 1999.

135 Ibid.

136 Ibid.

137 Ibid.

138 Ibid.

139 Liebenberg and Pillay Socio-Economic Rights in South Africa (publication Socio-economic Rights Project Community Law Centre, University of Western Cape South Africa) 351.

140 Berger 2003103 Columbia LR 625.

141 Woolman and Fleisch The Constitution in the Classroom: Law and Education in South Africa 1994-2008 128 and 129.

142 Ibid.
} 
children was done by the World Declaration on Education for All which defined the term basic education. The World Declaration states that,

"Every person - child, youth and adult - shall be able to benefit from educational opportunities designed to meet their basic learning needs. These needs comprise both essential learning tools (such as literacy, oral expression, numeracy, and problem solving) and the basic learning content (such as knowledge, skills, values, and attitudes) required by human beings to be able to survive, to develop their full capacities, to live and work in dignity, to participate fully in development, to improve the quality of their lives, to make informed decisions, and to continue learning. The scope of basic learning needs and how they should be met varies with individual countries $s$ and cultures, and inevitably, changes with the passage of time."

Basic education is the quality of education defined by the World Declaration and enabled by compulsory and free school attendance which must be provided immediately. The provision of basic learning needs is what is required at basic education level. ${ }^{144}$ The Schools Act aligning with the provisions of the World Declaration must be amended to clarify the foundational components which form a basic education curriculum. The foundational components of a basic education which are beyond the scope of this paper must follow its definition and description by the World Declaration although they can be contextualized to meet the needs of South Africa. National examinations can be used to test the competency of a learner in mastering basic learning needs. The goal for quality education is at the heart of the Education for All goals.

Whilst they agree that the term basic education points to the quality of education to be provided to children, it is notable that Woolman and Fleish state that, achieving the quality dimension of basic education "is unequivocally beyond the current reach of the South African educational system" due to the inadequacy of resources. ${ }^{145}$ This paper advances a point that, there is no constitutional goal which can be beyond the reach of the educational system. Basic education is an unqualified immediate obligation as stated above. The state has an obligation to provide it immediately. To do so, it must reallocate resources and revise its spending priorities in order to meet basic learning needs immediately.

\section{Component six: basic education provided by schools must be available, accessible, adaptable and acceptable}

\section{A functional school}

The Committee through General Comment number 13 elaborates that, if schools are to offer education such education given "shall exhibit the following interrelated and essential features", availability, accessibility,

143 Article 1(1) of World Declaration 1990.

144 Ibid.

145 Woolman and Fleisch The Constitution in the Classroom: Law and Education in South Africa 1994-2008 130. 
acceptability and adaptability. ${ }^{146}$ These elements do not define education or basic education but they are essential features which must be exhibited by a school which offers education. Authors like Churr also agree that the four interrelated elements, availability, accessibility and acceptability and adaptability are important essential features of a basic education. ${ }^{147}$ Arendse further states that the interrelated elements "give concrete content to the right to basic education". ${ }^{148}$ However, unlike Churr ${ }^{149}$ who may think of them only as "contributing to the successful provision of a basic education", this paper argues that, they are not the concrete content of the right to basic education but rather a component of the right to basic education together with its other elements discussed above.

\section{The four interrelated elements}

In relation to availability, the Committee states that education institutions (schools) which are functional must be available in sufficient quantity. ${ }^{150}$ Numerous factors determine availability inclusive of the developmental context where the educational institutions operate. ${ }^{151}$ These factors include the fact that any education institution needs buildings including elements like sanitation facilities for males and females, classrooms, functional and well stocked libraries as well as computer facilities. ${ }^{152}$ Schools must have safe drinking water, teachers that are trained with teaching materials and receiving salaries that are competitive. ${ }^{153}$ All the above factors hinge on the environment for learning for children. If the learning environment does not provide functional schools, then, the General Comment 13 is of the view that the education is not available. This means that if children in South Africa are going to schools with no classrooms, sanitation, trained teachers, teaching materials, libraries, and computer facilities or grounds for recreational activities, the view of the Committee is that their education is not available. In relation to availability what is of paramount importance are inputs which "should be adequate and of sufficient quality to create a teaching and learning environment capable of satisfying these needs". ${ }^{154}$ Physical resources are important for the production of educational outcomes. ${ }^{155}$ Any, "healthy measure of common sense" must lead to the conclusion that, "decent school facilities are in the vast majority of cases an important prerequisite for teaching and learning that is capable of satisfying basic learning needs".

For accessibility, the Committee states that it has three dimensions, firstly there should be no discrimination based on any ground in the provision of

146 Par 6a-6d of General Comment 13: The Right to Education 1999.

147 Chuur 2015 PER/PELJ 2414.

148 Arendse 201114 PER/PELJ 100.

149 Chuur 2015 PER/PELJ 2414.

150 Par 6 of General Comment 13: The Right to Education 1999.

151 Par 6a of General Comment 13: The Right to Education 1999.

152 Ibid.

153 Ibid.

154 McConnachie and McConnachie 2012 SALJ 568.

155 McConnachie and McConnachie 2012 SALJ 568-569.

156 Ibid. 
school education. ${ }^{157}$ Equal treatment of learners is an immediate state obligation at any school and it cannot be qualified even by resource availability. ${ }^{158}$ The need for equal provision of education by schools must be seen in light of the provisions of the CADE. ${ }^{159}$ State parties to the CADE agreed to enact national policies which would promote equality in accessing schools and equal treatment of prospective learners and these would include "making primary education free for all" whilst at the same time ensuring the provision of education of the same standards. ${ }^{160}$ Whilst a state can adopt temporary measures to ensure that there is a balance of provision of education in schools between different children, policies that result in different spending for different groups leading to different quality of basic education being offered by a school constitute discrimination. ${ }^{161}$ If budgets for schools in South Africa are unfairly different for schools in the same country or province then that education is deemed inaccessible.

Secondly, still regarding accessibility, schools must be physically accessible meaning that they must be within safe reach or convenient location. ${ }^{162}$ On this second leg of accessibility, the General Comment 13 is of the view that situations prevalent in South Africa where children walk long and oftentimes unsafe distances to school makes education inaccessible. ${ }^{163}$ Thirdly, still regarding accessibility, education must be economically accessible, particularly primary education must be free of charge. According to General Comment 11, free education means that primary schools must not charge entrance fees, exam fees or attendance fees for learners at the primary school level. ${ }^{164}$ The payment of school fees at basic education level is therefore against international law.

For acceptability, the content of school education, the delivery methods, assessments and the curriculum must be of good quality and relevant culturally aligning with the quality required by various international

157 Par $6 \mathrm{~b}$ of General Comment 13: The Right to Education 1999.

158 lbid.

159 Convention Against Discrimination in Education 1960. The Convention must be further read in light of other specific international instruments such as the Convention on the Elimination of Discrimination against Women 1979 and the International Convention on the Elimination of all forms of Racial Discrimination 1969 and the provisions of the South African Constitution on non-discrimination.

160 Par 6b of General Comment 13: The Right to Education 1999.

161 lbid.

162 Ibid.

163 As above.

164 Par 7 General Comment 111999 "Free of charge. The nature of this requirement is unequivocal. The right is expressly formulated so as to ensure the availability of primary education without charge to the child, parents or guardians. Fees imposed by the Government, the local authorities or the school, and other direct costs, constitute disincentives to the enjoyment of the right and may jeopardize its realization. They are also often highly regressive in effect. Their elimination is a matter which must be addressed by the required plan of action. Indirect costs, such as compulsory levies on parents (sometimes portrayed as being voluntary, when in fact they are not), or the obligation to wear a relatively expensive school uniform, can also fall into the same category. Other indirect costs may be permissible, subject to the Committee's examination on a case-by-case basis. This provision of compulsory primary education in no way conflicts with the right recognized in article 13.3 of the Covenant for parents and guardians to choose for their children schools other than those established by the public authorities." 
instruments. ${ }^{165}$ If the education offered by the government in South Africa is not of the quality required by international law as well as the provisions of the domestic law (which align with international law) then the education is not deemed acceptable. On education which is culturally relevant, education must be designed to suit the local needs of the learners and address various cultural issues otherwise it is not acceptable. ${ }^{166}$ For adaptability, school education must be flexible enough to adapt to the needs of the society and the communities in which it is provided. ${ }^{167}$ General Comment 13 stated that if an education does not exhibit the above essential features, it cannot qualify to be called an education.

\section{The South African position}

The Schools Act prescribes minimum norms and standards relating to infrastructure of a school, capacity of schools, curriculum and the provision of learning materials by the minister. ${ }^{168}$ In relation to minimum standards which make education available such as infrastructure, capacity and learning materials, the minister only has a discretion to prescribe them the law does not mandate her to prescribe them (author's own emphasis). ${ }^{169}$ The language of the Act states that she "may" and not she "must". The minister may therefore choose not to prescribe them which will be a decision which compromises the goal of making education available sanctioned by General Comment 13. If the prescription of norms and standards is to be maintained, the provisions of the Act need to be amended to ensure that the minister is

165 Par 6(c) of General Comment 13: The Right to Education 1999; Par 6a-6d of General lbid.

167 Par 6d of General Comment 13: The Right to Education 1999.

168 S 5 A of 84 of 1996 "Norms and standards for basic infrastructure and capacity in public schools -

(1) The Minister may, after consultation with the Minister of Finance and the Council of Education Ministers, by regulation prescribe minimum uniform norms and standards for - (a) school infrastructure; (b) capacity of a school in respect of the number of learners a school can admit; and (c) the provision of learning and teaching support material. [Sub-s (1) amended by s 5 of Act No. 15 of 2011].

(2) The norms and standards contemplated in subsection (1) must provide for, but not be limited to, the following: (a) In respect of school infrastructure, the availability of - (i) classrooms; (ii) electricity; (iii) water; (iv) sanitation; (v) a library; (vi) laboratories for science, technology, mathematics and life sciences; (vii) sport and recreational facilities; (viii) electronic connectivity at a school; and (ix) perimeter security; (b) in respect of the capacity of a school - (i) the number of teachers and the class size; (ii) quality of performance of a school; (iii) curriculum and extra-curricular choices; (iv) classroom size; and (v) utilisation of available classrooms of a school; (c) in respect of provision of learning and teaching support material, the availability of - (i) stationery and supplies; (ii) learning material; (iii) teaching material and equipment; (iv) science, technology, mathematics and life sciences apparatus; (v) electronic equipment; and (vi) school furniture and other school equipment.

(3) When determining policy in terms of sections 5 (5) and 6 (2) a governing body must comply with the norms and standards contemplated in subsection (1).

(4) A governing body must, within a period of 12 months after the Minister has prescribed the norms and standards contemplated in subsection (1), review any policy that it has determined in terms of sections 5 (5) and 6 (2) to ensure that such policy complies with 169 Ibid. the norms and standards." 
mandated to prescribe the minimum norms and standards. Further, the Act states that the minister when drafting the norms and standards must exercise her discretion in consultation with the minister of finance. ${ }^{170}$ Such a provision means that the issue of availability of resources may be taken into account before the norms and standards are prescribed. Norms and standards which tally with available resources may end up being prescribed which may end up disadvantaging children who are entitled to an unqualified right to basic education.

The Schools Act also provides a mere list which the minister must prescribe standards on such as stating library, furniture or sanitation without providing details. ${ }^{171}$ The Act must provide specifics on each item and not just a list. What is needed is for the Schools Act to expand its provisions and go into detailed foundational specific details. Mere mentioning of the word furniture cannot be enough. Citizens will be advantaged by the provision of specifics in the Act so that the appropriateness of the ministers' norms and standards can be measured against established legal parameters. When providing explanations, the Act must provide a leeway to make them context specific in some cases. By context specific an example is that, the Act can state that the classrooms in a certain province must have built-in air conditioning whilst the other province can have fans depending on the weather of each province. Context specific does not allude to discriminatory treatment but a recognition of peculiar contextual needs.

The benefit of more comprehensive legal frameworks is evidenced by the fact that in South Africa, citizens could have benefited from more clarity relating to the educational resources had it been provided by the Schools Act. In the case Madzodzo, ${ }^{172}$ which related to the availability of school education resources, the court stated that the right to basic education, "requires the provision of a range of educational resources: - schools, classrooms, teachers, teaching materials and appropriate facilities for learners". ${ }^{173}$ It was stated that the lack of age appropriate desks and chairs constituted a violation of the right to basic education. ${ }^{174}$ On the other hand, relating to the availability of teaching staff, the case of Centre for Child Law $v$ Minister of Basic Education (National Association of School Governing Bodies as amicus curiae) stated that the provision of teaching and nonteaching staff as well as teaching resources is a critical component of the right to basic education. ${ }^{175}$ The decisions of the above clearly shows that, instead of citizens having to hear it from the courts that schools must provide "age appropriate furniture", it is more convenient for the government to know

170 Ibid.

171 Ibid

172 Madzodzo v Minister of Basic Education supra par 1. "This matter concerns the impact of an alleged failure to provide essential school furniture, in the form of desks and chairs, to public schools throughout the Province and in particular in impoverished rural areas."

173 Madzodzo v Minister of Basic Education supra par 20.

174 Madzodzo $v$ Minister of Basic Education supra par 20. "It is clear from the evidence presented by the applicants that inadequate resources in the form of insufficient or inappropriate desks and chairs in the classrooms in public schools across the province profoundly undermines the right of access to basic education."

175 Centre for Child Law v Minister of Basic Education (National Association of School Governing Bodies as amicus curiae) supra par 32. 
the type of furniture, classrooms or libraries it must provide through the provisions in the law of general application.

In relation to acceptability of education, the minister is obligated to gazette the national curriculum which determines the minimum outcomes and standards of education as well as the procedures to assess the learner's achievements. ${ }^{176}$ The Schools Act does not provide specifics of the type of education the ministry of basic education must provide as well as its intended outcomes. The Schools Act must follow the recommendation of the Basic Education of Finland which provides for the objectives of basic education ${ }^{177}$ and the content of its syllabus. ${ }^{178}$ In addition, the Schools Act must define the term basic education. It must unpack basic learning needs required by the World Declaration including the way in which they must be taught and assessed. Concepts and phrases including knowledge, skills, values, literacy, oral expression and problem solving must be defined and explained. Guidance to define them can be sought from academic writings as they are read together with the provisions of international law instruments.

With respect to accessibility of education, it follows that basic education must be free of charge as discussed earlier. However, it is strongly recommended that provisions from the Basic Education of Finland which provide clarity on the need for free education such as "teaching, the necessary textbooks and other learning materials, and school equipment

176 S 6 A of 84 of 1996 "Section 6A.Curriculum and assessment -

(1) The Minister must, by notice in the Government Gazette, determine -

(a) a national curriculum statement indicating the minimum outcomes or standards; and (b) a national process and procedures for the assessment of learner achievement.

(2) The curriculum and the process for the assessment of learner achievement contemplated in subsection (1) must be applicable to public and independent schools.

177 S 2 of 84 of 1996 "Objectives of education -

(1) The purpose of education referred to in this Act is to support pupils' growth into humanity and into ethically responsible membership of society and to provide them with knowledge and skills needed in life. Furthermore, the aim of pre-primary education, as part of early childhood education, is to improve children's capacity for learning.

(2) Education shall promote civilisation and equality in society and pupils' prerequisites for participating in education and otherwise developing themselves during their lives.

(3) The aim of education shall further be to secure adequate equity in education throughout the count."

178 S 11 of 84 of 1996 "Content of education -

(1) The basic education syllabus shall contain, as enacted by virtue of Section 14 , the following core subjects: mother tongue and literature, the second national language, foreign languages, environmental studies, health education, religious education or ethics, history, social studies, mathematics, physics, chemistry, biology, geography, physical education, music, art, crafts, and home economics. Education may, as enacted by virtue of Section 14, be based on syllabi of different extent. Providers of basic education who have been assigned a special educational mission under Section 7 or 8 may deviate from the provisions of this subsection (Amendment 453/2001).

(2) A pupil may be taught subjects suited for basic education other than those referred to in subsection 1, as determined in the curriculum. These subjects may be partly or totally free-choice or optional.

(3) The pupil shall be given guidance counselling.

(4) Notwithstanding the provisions of this Section, pre-primary education, additional voluntary education and education preparing for basic education shall be governed by the provisions of Section 14". 
and materials [must be] be free of charge" also "a pupil attending basic education [must] be provided with a balanced and appropriately organized and supervised free meal on every school day" be utilised in the Schools Act. ${ }^{179}$ In relating to access to enrolment, the Constitution is not discriminatory and access to basic education is for everyone as discussed earlier on. It is however noted that children of undocumented migrants, asylum seekers or refugees often face difficulties when desiring to access education. It must be noted that the unqualified nature of basic education demands its provision for all children whether or not they are documented and the word "everyone" provided by section 29(1)(a) must testify to the universal nature of the right to basic education in South Africa.

\section{CONCLUSION}

The lack of understanding of the scope and content of basic education is a problem which cannot remain unresolved. This paper explained the scope and content of the right to basic education provided by the Constitution of South Africa. The knowledge of the scope and content of basic education provided by this paper is not important on its own; the obligation by the ICESCR in relation to education is for countries to have an enabling legal framework. The scope and content of a basic education must be explained more in legislation and less in policy. Legal frameworks have an advantage of undoubtable enforceability as opposed to policy which is easily changeable and can be manipulated through furthering the interest of political parties. Important aspects of education such as the obligation to determine curriculum, language, classroom capacity, library, water, electricity, school furniture and equipment should not be left to the minister to determine through norms and standards. The intricate components of basic education could benefit from the punitive aspect of the law in the event of government's failure to comply.

179 Basic Education Act 628/1998. 